\title{
NOTES
}

\section{BANKERS LIFE: PAYING FOR A CORPORATION BY SELLING ITS SECURITIES VIOLATES 10b-5}

Securities fraud and the rule which prohibits it, the ubiquitous $10 \mathrm{~b}-5,{ }^{1}$ are familiar terms in the complex field of securities regulation. ${ }^{2}$ From comparatively modest beginnings ${ }^{3}$ the coverage of the rule has expanded to the point that $10 \mathrm{~b}-5$ has been said to form the basis for federal corporation law. ${ }^{4}$ This development has taken place

1. 17 C.F.R. \& $240.10 \mathrm{~b}-5$ (1971).

THE FOLLOWING HEREINAFTER CITATIONS WILL BE USED IN THIS NOTE:

A. Bromberg, Securities Law: Fraud-SEC Rule 10B-5 (1968) thereinafter cited as BROMBERG];

L. Loss, Securities Regulation (2d ed. 1961) [hereinafter cited as Loss].

2. In what is probably the only treatise devoted to a single administrative rule, the author asserts:

It now appears once or twice a week in reported cases and represents about one-third of all current cases, public and private, under the whole array of SEC statutes. . . . 10b5 is generating almost as much litigation as all the other general antifraud provisions together. . . . It is by now such a dominant factor in private securities litigation that one is surprised when it does not turn up, and a court does not hesitate to introduce it as a major consideration if the plaintiff fails to plead it. BROMBERG $\S 2.5(\mathrm{~b})$.

3. Milton Freeman, the author of the rule, has stated that it was drafted hastily:

I looked at Section 10(b) and I looked at Section 17, and I put them together, and the only discussion we had there was where "in connection with the purchase or sale" should be, and we decided it should be at the end. Conference on Codification of the Federal Securities Laws, 22 Bus. Law. 793, 922 (1967) (speech by Milton V. Freeman).

Section 10 (b) was promulgated in reponse to a specific scheme:

[T] he president of some company [was] . . going around buying up the stock of his company from his own shareholders at $\$ 4.00$ a share, and he has been telling them that the company is doing very badly, whereas, in fact, the earnings are going to be quadrupled and will be $\$ 2.00$ a year for the coming year. Id.

Approval was virtually without discussion:

Nobody said anything except Sumner Pike, who said, "Well, . . . we are against fraud, aren't we?"' Id.

4. See, e.g., Ruder, Pitfalls in the Development of a Federal Law of Corporations by Implication Through 10b-5, 59 Nw. U.L. REv. 185 (1964) for a critical discussion of this trend. Professor Cary, W. Cary, Cases and Materials on Corporations 14 (4th ed. 1969), claims credit for first using the term "federal corporation law" in the previous edition of his casebook, R. Baker \& W. CARY, CASes and Materials on Corporations 564 (3d ed. 1958). It has been used in at least two cases: McClure v. Borne Chem. Co., 292 F.2d 824, 834 (3d Cir.), 
almost exclusively in the district courts and circuit courts of appeals with only one Supreme Court interpretation of $10 \mathrm{~b}-5$ in the nearly thirty years of its existence. ${ }^{5}$ Recently, however, the Supreme Court re-entered the arena of $10 \mathrm{~b}-5$ adjudication, ruling, in Superintendent of Insurance of New York v. Bankers Life and Casualty Co. ${ }^{6}$ that a liquidator/plaintiff bringing a derivative suit ${ }^{7}$ states a cause of action under section 10(b) of the Securities Exchange Act of $1934^{8}$ and rule $10 \mathrm{~b}-5$ by alleging that the corporation's sole shareholder fraudulently misappropriated for his own uses the proceeds of a sale of government bonds held by the corporation. This Note will summarize the facts and various holdings in the litigation of Bankers Life, discuss the pre-Bankers Life parameters in 10b-5 adjudication, and analyze the Supreme Court's opinion in Bankers Life, in order to determine what effect, if any, the case will have on the development of rule 10b5 .

In the fall of 1961, Bankers Life and Casualty Company (Bankers Life) agreed to sell its wholly-owned subsidiary, Manhattan Casualty Company (Manhattan), to James Begole for five million dollars. ${ }^{9}$ Prior to the closing in January, 1962, Begole borrowed the five million dollars from Irving Trust Company, receiving a check drawn on Irving Trust which he used to pay Bankers Life for its delivery of all of the outstanding shares of Manhattan. On the same day, Begole caused Manhattan to sell government bonds with a face value of five million dollars, depositing the proceeds of this sale in a newly created Manhattan account at the Irving Trust Company. Irving Trust

cert. denied, 368 U.S. 939 (1961); Cady, Roberts \& Co., 40 S.E.C. 907, 910 (1961). See also Fleischer, "Federal Corporation Law:" An Assessment, 78 HaRv. L. REv. 1146 (1965); Friendly, In Praise of Erie and the New Federal Common Law, 39 N.Y.U.L. REv. 384, 41314 (1964).

5. SEC v. National Sec., Inc., 393 U.S. 453 (1969). The rule was promulgated (as Rule X10B-5) in 1942. See SEC Securities Exchange Act Release No. 3230 (May 21, 1942), reprinted in BROMBERG 295. (Editor's Note: Since this Note was written the Supreme Court has decided another 10b-5 case. Affiliated Ute Citizens v. United States, 40 U.S.L.W. 4448 (U.S. Apr. 24, 1972). See note 41 infra).

6. 404 U.S. 6 (1971).

7. The Superintendent's standing was based on a New York statute:

The Superintendent and his successors shall be vested by operation of law to all of the ... rights of action of such insurers as of the date of the entry of the order so directing them to liquidate. N.Y. INS. LAw $\S 514$ (McKinney 1966).

8. 15 U.S.C. $\S 78 \mathrm{j}(\mathrm{b})(1970)$.

9. The facts are stated in greater detail in the opinion of the district court, $300 \mathrm{~F}$ : Supp. 1083, 1087-92 (S.D.N.Y. 1969). 
charged its check for the purchase of the Manhattan shares against this account. Begole and his associates then engaged in a series of complicated transactions through which Begole manipulated Manhattan's books to reflect only the sale of its government bonds and the purchase of a five million dollar certificate of deposit. ${ }^{10}$ The corporation's books did not show that Manhattan's assets had been depleted or that Begole had used the proceeds of the bond sale to finance his acquisition of Manhattan's stock from Bankers Life. Some time subsequent to these transactions, the Superintendent of Insurance of the State of New York declared Manhattan insolvent and commenced liquidation proceedings. ${ }^{11}$

After an abortive attempt to sue in the state courts, ${ }^{12}$ the Superintendent of Insurance, in his derivative capacity as liquidator, ${ }^{13}$ brought an action in the United States District Court for the Southern District of New York, ${ }^{14}$ naming as defendants Begole, Bankers Life, Irving Trust, and other individuals and banking institutions that had participated in the sale of control of Manhattan, the subsequent misappropriation of the proceeds from the sale of the bonds, and the attempt to camouflage the true nature of the transactions. Asserting that he had standing to sue by virtue of the fact that Manhattan was the purchaser of its own stock, the Superintendent argued that the transactions, when integrated, revealed a scheme to defraud Manhattan and its creditors in violation of section 17(a) of the Securities Exchange Act of 1933. ${ }^{15}$ The district court rejected this claim, saying that it is conceptually impossible for a corporation to purchase all of

10. 404 U.S. at 8. Irving Trust issued another check for five million dollars to Manhattan. The president of Manhattan tendered this check to Belgian-American Bank \& Trust Co. which then issued a five million dollar certificate of deposit in the name of Manhattan. This certificate of deposit was carried on Manhattan's books as an asset, but was, in fact, later endorsed to New England Note Corp., controlled by an associate of Begole's. The New England Note Corp. endorsed the certificate to Belgian-American Banking Corp. as collateral for a five million dollar loan. The proceeds of the loan were then turned over to Irving trust.

11. The relevant statutes are N.Y. INs. LAw $\$ 93$ (defining insolvency of an insurer), 511 (a) (stating insolvency of an insurer as a ground for liquidation), and 513 (permitting the superintendent of insurance to liquidate insurance companies) (McKinney 1966).

12. The plaintiff had first brought suit in the New York County Supreme Court in 1965 alleging common law fraud. The factual allegations of the earlier complaint were essentially the same as those filed in the district court. After joinder of claims in the state case, further proceedings in the action had been enjoined. 300 F. Supp. at 1104 n.17.

13. See note 7 supra.

14. 300 F. Supp. 1083 (1969).

15. 15 U.S.C. $\S 77 q(a)(1970)$. 
its outstanding shares without dissolution, because a corporation may not exist unless some other person or entity serves as proprietor or owner. ${ }^{16}$ Further, the court noted that Manhattan was not a purchaser within the meaning of section 17(a) since it did not qualify as "one who was a party to a transaction whereby he was to assume ownership of securities in exchange for valuable consideration."17 The plaintiff then orally amended his complaint in open court, arguing that Manhattan's sale of the bonds, Begole's misappropriation of the proceeds, and the cover-up transactions involving the certificates of deposit gave rise to a cause of action under section 10(b) of the 1934 Act and rule 10b-5. Withholding judgment as to the propriety of oral modifications to pleadings, ${ }^{18}$ the court found that Manhattan was clearly a seller of the government bonds and thus, as to the threshold issue of standing, was empowered to maintain an action on that sale.

Turning to the merits of the claim, the district court ruled that mere allegations of fraudulent misappropriation of proceeds from the sale of bonds did not state a cause of action cognizable under rule 10b-5. Drawing from other $10 \mathrm{~b}-5$ cases, the court reasoned that the rule was designed to maintain the integrity of the securities market. ${ }^{10}$ Since Manhattan sold the bonds for their full value, the court was persuaded that the integrity of the securities market was unblemished by the misappropriation of the proceeds after the sale. ${ }^{20}$ In so deciding, the court stated:

the consummation of a security transaction as a mere incident of a fraudulent scheme and the mere fact of injury caused by the fraud, in the absence of any

16. 300 F. Supp. at 1098.

17. Id.

18. Id. Modification was allowed by the court since a complaint which states facts with sufficient clarity to give adequate notice of the transaction and which would allow relief under any legal theory is generally deemed sufficient. $I d$. at 1093, citing 1A W. BARRON \& A. Holtzoff, Federal Practice \& Procedure § 276.1 (Wright ed. 1960) and 2A J. Moore, Federal Practice- Tl 8.14 (2d ed. 1968).

19. $300 \mathrm{~F}$. Supp. at 1101 . The court, id. at 1102-04, found that impairment of the purity of the market was the common denominator of these cases: Schoenbaum v. Firstbrook, 405 F.2d 215 (2d Cir. 1968), cert. denied sub nom. Manley v. Schoenbaum, 395 U.S. 906 (1969); Mutual Shares Corp. v. Genesco, Inc., 384 F.2d 540 (2d Cir. 1967); A.T. Brod v. Perlow, 375 F.2d 393 (2d Cir. 1967) (manipulative effect on the market); Ruckle v. Roto Am. Corp., 339 F.2d 24 (2d Cir. 1964); Hooper v. Mountain States Sec. Corp., 282 F.2d 195 (5th Cir. 1960), cert. denied, 365 U.S. 814 (1961) (danger of watered stock); Pettit v. American Stock Exch., 217 F. Supp. 21 (S.D.N.Y. 1963) (abuse of the trading process).

20. $300 \mathrm{~F}$. Supp. at 1104 . The reference here is to the time when the proceeds from the sale of Manhattan's bonds were used to pay off the loan from Irving Trust-a time clearly after the sale of the bonds. 
possibility that the fraud might materially affect the purity of the security transaction and the purity of the trading process would not make the fraud federally cognizable. ${ }^{21}$

Finding an analogy in conspiracy cases, the district judge further noted that "Rule 10b-5 requires the employment of fraud in connection with a security transaction, which is essentially different from the effectuation of a security transaction in connection with a fraudulent activity." ${ }^{22}$ A legal act in furtherance of a conspiracy may be part of the proof of the existence of a conspiracy, but such act is not independently punishable. Similarly, the sale of the bonds did not give rise to a cause of action; the proscribed activity was looting the corporation, a breach of fiduciary duty punishable under state law but not under the 1934 Act.

The Court of Appeals for the Second Circuit affirmed, ${ }^{23}$ utilizing basically the same rationale employed by the district court judge. It distinguished the fraud by Begole from 10b-5 fraud in that Begole's sole object was to obtain possession of the bonds for his personal use rather than to affect either the securities market or the investing public. The sales transaction itself was not tainted since the purchaser paid the full and fair market price for the bonds. Rather, the fraud lay in the subsequent misappropriation of the proceeds, an act involving waste of Manhattan's corporate assets and giving rise to a claim cognizable only under state law. The court conceded that the Securities Exchange Act gave the SEC power to promulgate rules "appropriate in the public interest" as well as "for the protection of investors," and agreed that the public interest was involved when a corporation which is subject to regulation by the state Superintendent of Insurance is defrauded. ${ }^{24}$ The court of appeals nevertheless maintained that "the public interest cognizable by section $10(b)$ is limited to preserving the integrity of the securities markets." ${ }^{25}$ The securities acts were not, it reasoned, designed to "create an unlimited federal right of action for damages for all who have been defrauded in any area of economic activity." 26

The Supreme Court, in an unanimous opinion written by Justice Douglas, reversed and remanded the case for a new trial against all

\footnotetext{
21. Id. at 1101 .

22. Id. at 1102 .

23. 430 F.2d 355 (2d Cir. 1970).

24. Id. at 361 .

25. Id. (emphasis added).

26. Id.
} 
defendants. ${ }^{27}$ The most important factor in the Court's disposition of the case was that Manhattan and the community of interest it represented-the policyholders and creditors-had "suffered an injury as a result of deceptive practices touching its sale of securities as an investor." 28 The Court agreed with the lower tribunals that Manhattan had standing under rule 10b-5 as a seller of the bonds. ${ }^{29}$ It found, however, that the fraud was not limited to a misappropriation of proceeds, but was definitely in connection with the sale, since the "seller was duped into believing that it, the seller, would receive the proceeds." 30 The fact that the complaint alleged deceit of Manhattan by its sole shareholder created no conceptual problems for the Court. Reasoning that $10 \mathrm{~b}-5$ recovery is not limited to those types of fraud which adversely affect the integrity of the securities market, ${ }^{31}$ the Court found it irrelevant that the fraud involved a misappropriation of proceeds from the sale of a security rather than the more commonly encountered sale of a security for an inadequate consideration. ${ }^{32}$ According to the Court's analysis, the requisites of $10 \mathrm{~b}-5$ culpability are met whenever there is a sale of a security and fraud in connection with that sale. Further, it noted that the fraud requirement is satisfied by an allegation of breach of fiduciary duty even if those who are injured by such a breach are non-investors, in this case, the creditors of the defrauded corporation. ${ }^{33}$

\section{Prior Judicial Treatment of Rule 10b-5}

Section 10(b) of the Securities Exchange Act of 1934 declares it to be illegal "[t]o use or employ, in connection with the purchase or sale of any security ... any manipulative or deceptive device . . . ."34 Rule 10b-5 makes it unlawful for any person to employ any artifice, scheme, or device to defraud; to state, or to fail to state, any

27. 404 U.S. 6 (1971).

28. Id. at 12-13 (emphasis added).

29. Id. at 9. See text following note 18 supra for a discussion of Manhattan's standing as a defrauded seller of securities.

30. Id.

31. Id. at 10,12 .

32. Id. The Court's language on this point is confusing: "Likewise irrelevant is the fact that the proceeds of the sale that were due the seller were misappropriated." Since there would have been no suit if there had been no misappropriation, it is assumed that the Court meant that it regarded the fact that the fraud involvcd a misappropriation of proceeds, rather than some other, nore commonly encountered scheme, was irrelevant.

33. Id. at 12.

34. 15 U.S.C. $\S 78 j(b)$ (1970). 
material fact which, with regard to the surrounding circumstances, would be misleading; or to participate "in any act, practice, or course of business which operates or would operate as a fraud or deceit upon any person, in connection with the purchase or sale of any security." 35 Although the rule does not expressly provide for civil liability, since Kardon v. National Gypsum $\mathrm{Co}^{36}$ the courts have held that civil redress is available to a defrauded claimant. Further, 10b-5 claimants have not been subjected to a rigid adherence to the common-law elements of fraud. ${ }^{37}$ Depending on the policy sought to be protected, ${ }^{38}$ the courts have emphasized or minimized such traditional fraud requirements as privity, ${ }^{39}$ scienter, ${ }^{40}$ and reliance. ${ }^{41}$

35. 17 C.F.R. $\$ 240.10$ b-5 (1971).

36. 69 F. Supp. 512, modified, 73 F. Supp. 798 (E.D. Pa. 1946), modified, 83 F. Supp. 613 (E.D. Pa. 1947).

37. See, e.g., Mutual Shares Corp. v. Genesco, Inc., 384 F.2d 540, 544 (2d Cir. 1967); Stevens v. Vowell, 343 F.2d 374, 379 (10th Cir. 1965). See generally BromberG $\S 2.7(1)$ and authorities cited therein. For a discussion of the common law elements of fraud see W. PROSSER, THE LAw of TORTS $\$$ 100-03 (3d ed. 1964). See also Cady, Roberts \& Co., 40 S.E.C. 907, 910 (1961).

38. A few of the sometimes conflicting, often unarticulated, policy considerations that might influence a court's decision are: (1) the court's concern that business executives, seemingly innocent of any intentional wrongdoing, not be subjected to liability under the federal fraud statutes; (2) the court's hesitation to expand federal corporation law; and (3) the court's desire to give the fullest protection to the investing public.

39. Compare Freed v. Szabo Food Serv., Inc., [1961-64 Transfer Binder] CCH Fed. SEC. L. ReP. I 91,317 (N.D. 111. 1964) and Cochran v. Channing Corp., 211 F. Supp. 239, 243-44 (S.D.N.Y. 1962) with Meisel v. North Jersey Trust Co., 218 F. Supp. 274 (S.D.N.Y. 1963). Without using the word "privity" the Second Circuit seems to have rejected it as a requirement. SEC v. Texas Gulf Sulphur Co., 401 F.2d 833, 860 (2d Cir. 1968), cert. denied sub nom. Kline v. SEC, 394 U.S. 976 (1969). See Ruder, Texas Gulf Sulphur-The Second Round: Privity and State of Mind in Rule l0b-5 Purchase and Sale Cases, 63 Nw. U.L. Rev. 423, 444 n. 107, 448 (1968). See generally Bromberg $§ 8.5$; Loss 1767; Comment, Civil Liability Under Section $1 O B$ and Rule lOB-5: A Suggestion for Replacing the Doctrine of Privity, 74 YALE L.J. 658 (1965).

40. See SEC v. Van Horn, 371 F.2d 181 (7th Cir. 1966); Kohler v. Kohler Co., 319 F.2d 634 (7th Cir. 1963); Ellis v. Carter, 291 F.2d 270, 274 (9th Cir. 1961); Texas Continental Life Ins. Co. v. Bankers Bond Co., 187 F. Supp. 14 (W.D. Ky. 1960), rev'd on other grounds sub nom. Texas Continental Life Ins. Co. v. Dunne, 307 F.2d 242 (6th Cir. 1962). But see Weber v. C.M.P. Corp., 242 F. Supp. 321 (S.D.N.Y. 1965); Trussel v. United Underwriters, Ltd., 228 F. Supp. 757 (D. Colo. 1964); cf. Dack v. Shanman, 227 F. Supp. 26 (S.D.N.Y. 1964). See generally BRomberG § 8.4; Epstein, The Scienter Requirement in Actions Under 10b-5, 48 N.C.L. REv. 482 (1970); Ruder, supra note 39, at 446; Note, Proof of Scienter Necessary in a Private Suit Under SEC Anti-Fraud Rule l0b-5, 63 MICH. L. REv. 1070 (1965).

41. The Supreme Court has rejected the element of reliance for a $10 \mathrm{~b}-5$ recovery when material facts were not disclosed. Affiliated Ute Citizens v. United States, 40 U.S.L.W. 4448 (U.S. Apr. 24, 1972). See also SEC v. Texas Gulf Sulphur Co., 401 F.2d 833, 963-64 (2d Cir. 1968); Speed v. Transamerica Corp., 99 F. Supp. 808 (D. Del. 1951); Ruder, Civil Liability 
The major obstacle to prospective $10 \mathrm{~b}-5$ plaintiffs has been the Second Circuit's decision in Birnbaum v. Newport Steel Corp., ${ }^{42}$ where the minority shareholders of a corporation sued the present and former majority shareholder alleging fraud in connection with the sale of his majority interest in the company at a premium. The court analyzed the history of the 1934 Act and decided that the minority shareholders lacked standing to sue. ${ }^{43}$ In so holding, the Second Circuit established the purchaser-seller obstacle:

[Section 10] was directed solely at that type of misrepresentation or fraudulent practice usually associated with the sale or purchase of securities rather than at fraudulent mismanagement of corporate affairs, and . . Rule X-10B-5"4 extended protection only to the defrauded purchaser or seller. ${ }^{\text {t5 }}$

Since this purchaser-seller requirement operates to deny plaintiffs a federal forum ${ }^{46}$ and the procedural advantages of $10 \mathrm{~b}-5,{ }^{47}$ the pressures on it have been relentless. The SEC has urged that Birnbaum be overruled in several amicus appearances. ${ }^{48}$ While some commentators consider the purchaser-seller requirement to be sound, ${ }^{49}$ most

Under 10b-5: Judicial Revision of Legislative Intent?, 57 Nw. U.L. REv, 627, 678 (1963). See generally BROMBERG \& 8.6(1), (2).

42. 193 F.2d 461 (2d Cir.), cert. denied, 343 U.S. 956 (1952).

43. 193 F.2d at 464 .

44. X-10B-5 was the original designation; the wording was identical to 17 C.F.R. $\$ 240.10 \mathrm{~b}-5$ (1971). See note 5 supra.

45. 193 F.2d at 464 (emphasis added).

46. The federal courts are vested with exclusive jurisdiction to enforce the securities laws. 15 U.S.C. $\S 78$ aa (1970). A plaintif barred by the purchaser-seller requirement from asserting a federal claim must find some independent source of jurisdiction, such as diversity of citizenship, and would also have to allege damages of at least $\$ 10,000$ to bring suit in the federal courts. Among the advantages to bringing suit under the Securities Acts, rather than state "Blue Sky" laws, are more liberal discovery provisions, a generally more sympathetic judiciary, and in difficult cases presenting novel questions, the help of the SEC as amicus. See generally BROMBERG $§ 2.7(1)-(3)$.

47. For example, in addition to the advantages generally enjoyed by litigants in the federal courts, the 10b-5 plaintiff enjoys relaxed venue requirements and world-wide service of process. See BROMBERG $\$ 11.3,11.4$. A $10 \mathrm{~b}-5$ action is preferable even to one brought under the overlapping provisions of $\S 17$ (a) of the 1933 Act; see Loss 1782-90.

48. See, e.g., Vine v. Beneficial Fin. Co., 374 F.2d 627, 633 n.6 (2d Cir.), cert. denied, 389 U.S. 970 (1970): Brief for SEC, 119 BNA SEC. REG. L. REP. A-8 (Sept. 22, 1971) (where the SEC argued that the purchaser-seller doctrine was a judicially established limitation not necessarily required by the language of the rule).

49. See, e.g., Loss 1469; Bradford, Rule 10b-5: The Search for a Limiting Doctrine, 19 Buffalo L. REv. 205, 210 (1970); Comment, The Expanding Uses of Rule 10b-5, 10 B.C. IND. \& COM. L. REV, 313; 316-17 (1969). 
denounce it, ${ }^{50}$ including one well-known conservative who is critical of the sweep of $10 \mathrm{~b}-5 .^{51}$ It has been pronounced dead by a hopefulis2 commentator and at least two lower court judges.53 Nevertheless, although it has suffered as many blows at the hands of its enemies as Rasputin, it has, like the mad monk, continued to show an amazing vitality at least where the plaintiffs seek money damages. ${ }^{54} \mathrm{Per}$ haps the factor contributing most to the survival of the purchaserseller requirement has been the willingness of courts to expand the definitions of purchase and sale to include contracts to purchase or sell, ${ }^{55}$ "constructive sales," ${ }_{56}$ aborted sales, ${ }^{57}$ mergers in which stock is traded rather than exchanged for money, ${ }^{58}$ even to unconsummated mergers $^{59}$ and resolutions to liquidate. ${ }^{80}$

Several other prerequisites to $10 \mathrm{~b}-5$ actions have been discarded

50. See, e.g., Lowenfels, The Demise of the Birnbaum Doctrine: $A$ New Era for Rule 10b5, 54 VA. L. Rev. 268 (1968); Comment, The Purchaser-Seller Rule: An Archaic Tool for Determining Standing Under Rule 10b-5, 56 GEO. L.J. 1177 (1968); Comment, SEC Rule X10B-5: Guided Missile or Flying Saucer?, 32 TEx. L. REv. 197, 206 (1953); Comment, Private Enforcement Under Rule 10b-5: An Injunction for a Corporate Issuer?, 115 U. PA. L. Rev. 618, 622 (1967); Note, The Purchaser-Seller Limitation to SEC Rule 10b-5, 53 CORNELL L.Q. 684, 697-99 (1968); Note, Civil Liability Under Rule X-10b-5, 42 VA. L. Rev. 537, 570 (1956).

51. Ruder, Current Developments in the Federal Law of Corporate Fiduciary Relations - Standing to Sue under Rule 10b-5, 26 Bus. Law. 1289 (1971). Mr. Ruder has written several articles criticizing judicial expansion of rule 10b-5. See, e.g., Ruder, supra notes 4 \& 41.

52. Lowenfels, supra note 50.

53. Tully v. Mott Supermarkets, lnc., 337 F. Supp. 834 (D.N.J. 1972); Entel v. Allen, 270 F. Supp. 60, 70 (S.D.N.Y. 1967); see text accompanying notes 109-11 infra.

54. Injunctive relief has been granted to plaintiffs who were neither purchasers nor sellers of securities. See, e.g., Britt v. Cyril Bath Co., 417 F.2d 433 (6th Cir. 1969); Mutual Shares Corp. v. Genesco, Inc., 384 F.2d 540 (2d Cir. 1967). However, where damages are sought, the continued existence of the requirement has been affirmed. See, e.g., lroquois Indus., Inc. v. Syracuse China Corp., 417 F.2d 963 (2d Cir. 1969), cert. denied, 399 U.S. 909 (1970); Greenstein v. Paul, 400 F.2d 580 (2d Cir. 1968).

55. See, e.g., Goodman v. H. Hentz \& Co., 265 F. Supp. 440 (N.D. 111. 1967); M.L. Lee \& Co. v. American Cardboard \& Packing Corp., 36 F.R.D. 27 (E.D. Pa. 1964).

56. See, e.g., Crane Co. v. Westinghouse Air Brake Co., 419 F.2d 787 (2d Cir. 1969), cert. denied, 400 U.S. 822 (1970); Vine v. Beneficial Fin. Co., 374 F.2d 627 (2d Cir.), cert. denied, 389 U.S. 970 (1967).

57. Neuman v. Electronic Specialty Co., [1969-70 Transfer Binder] CCH FED. SEC. L. REP. ๆ 92,591 (N.D. III. 1969).

58. Mader v. Armel, 402 F.2d 158 (6th Cir. 1968), cert. denied sub nom. Young v. Mader, 394 U.S. 930 (1969). See also Note, Securities Regulation-Statutory Merger Involves a "Purchase" or "Sale" Under Section lO(b), 36 Ford. L. Rev. 632 (1967).

59. Herpich v. Wallace, 430 F.2d 792, 809-10 (5th Cir. 1970).

60. Coffee v. Permian Corp., 434 F.2d 383 (5th Cir. 1970). 
or relaxed by the courts. The other Birnbaum requirements, ${ }^{01}$ for instance, have been far less hardy than the purchaser-seller doctrine. When shareholders began bringing derivative actions alleging 10b-5 violations with respect to corporate stock, acts of fraudulent corporate mismanagement involving the sale of such stock for inadequate consideration were brought within the ambit of the rule. ${ }^{22}$ The requirement that the fraud be of the sort usually associated with securities transactions has been expressly repudiated by the circuit which imposed it. ${ }^{63}$ Finally, in deciding whether the fraud alleged was "in connection with a purchase or sale of securities" courts have, without the benefit of a consistent rationale, loosened the necessary connection. ${ }^{84}$

\section{Analysis of Bankers Life}

At first glance, the Supreme Court's opinion does not appear to break new ground in rule 10b-5 adjudication. Manhattan was clearly a satisfactory Birnbaum seller of the bonds, and as an investor was duped into selling its securities for nothing. ${ }^{.5}$ Further, in finding 10b5 fraud where the event fulfilling the deceitful purpose took place after the securities transaction which gave the plaintiff standing, the Court could look to the Second Circuit itself for precedent. ${ }^{66} \mathrm{~A}$ close

61. See text accompanying notes $44-45$ supra and notes $62-63$ infra.

62. Schoenbaum v. Firstbrook, 405 F.2d 215 (2d Cir. 1968), cert. denied sub nom. Manley v. Schoenbaum, 395 U.S. 906 (1969).

63. A.T. Brod \& Co. v. Perlow, 375 F.2d 393 (2d Cir. 1967).

64. See Comment, SEC Rule 10b-5 "In Connection with the Purchase or Sale of Any Security" Restriction: Need for Analytical Precision, 5 Colum. J. Soc. Prob. 28, 32 (1969).

65. The Superintendent alleged that Begole deccived an innocent board of directors into authorizing the sale by telling them that the proceeds were to be used to purchase a ccrtificate of deposit. Since the instant case involved only the motion to dismiss, the plaintiffs allegations were accepted as being true. As the district court pointed out, however, the evidence strongly pointed to the conclusion that the president of Manhattan and the board which authorized the sale were Begole's henchmen. 300 F. Supp. at 1089 n.6. Even if the facts in Bankers Life were such, the Second Circuit has held that the deceit requirements of rule 10b-5 are satisfied when the corporation's complaint alleges a breach of fiduciary duty by a corporation's entire board of directors in connection with that corporation's purchase or sale of securities. Schoenbaum v. Firstbrook, 405 F.2d 215 (2d Cir. 1968), discussed in Notc, Breach of Fiduciary Duty Involving Full Director Knowledge Held 10b-5 Violation, 1969 DuKE L.J. 383. More recently the Fifth Circuit has held that a corporation can be deceived by a scheme in which all of its officers, directors, and stockholders took part. Bailes v. Colonial Press, Inc., 444 F.2d 1241 (5th Cir. 1971). See Note, Fiduciary Suit Under Rule 10b-5, 1968 DUKE L.J. 791, 795-98, for a discussion of "deccit" of a corporation by its directors.

66. A.T. Brod \& Co. v. Perlow, 375 F.2d 393 (2d Cir. 1967). Perlow was a "free rider," an investor who ordered sccurities from a broker, and planned to resell them before the time 
scrutiny of the opinion, however, raises several questions as to whether-and to what extent-the reach of the rule has been extended. It is arguable that the Court has significantly enlarged both the categories of offenses under $10 \mathrm{~b}-5$ and the class of parties protected by the rule.

\section{New I0b-5 Violations}

Integrated Scheme to Sell Securities and Misappropriate Proceeds. Prior cases involving allegations of fraudulent mismanagement sufficient to state a $10 \mathrm{~b}-5$ cause of action were distinguishable from Bankers Life in one respect-considered vital until the Supreme Court declared it irrelevant. In previous cases, the stock which formed part of the capitalization of the company was sold for an inadequate consideration. ${ }^{67}$ In Bankers Life a corporate asset, held for investment, was converted to cash, which was then misappropriated by the holder of all of the capital stock of the company. ${ }^{68}$ In the former situation, the sale of securities forming the capitalization is the sine qua non of the fraud, the purpose of which is to cheat the company by transferring a share of the equity at an unfair "bargain" price. While the transfer of shares at an improperly determined price has been a $10 \mathrm{~b}-5$ violation from the inception of the rule, ${ }^{69}$ the Bankers Life holding extends $10 \mathrm{~b}-5$ to reach fraudulent practices whenever they incidentally involve securities transactions. In contending that 10b-5 had been violated, the Superintendent argued that there would have been no fraud without a sale of securities, and no sale of securities without fraud; therefore, there was fraud in connection with the sale. ${ }^{70}$ Although this line of reasoning ultimately prevailed in Bankers Life, it is nonetheless troublesome when Begole's scheme is more closely analyzed. The Supreme Court's decision turned on the fact that Begole accomplished his goal of looting Man-

\footnotetext{
due for payment-if the securities increased in value. If the price of the securities declined he would refuse to pay, forcing the broker to resell the securities at a loss. The defrauded broker acquired standing as a "purchaser" when he bought the securities for Perlow. The event fulfilling the fraudulent purpose occurred when Perlow reneged on payment-after the broker's purchase.

67. See, e.g., Schoenbaum v. Firstbrook, 405 F.2d 215 (2d Cir. 1968); Hooper v. Mountain States Sec. Corp., 282 F.2d 195 (5th Cir. 1960).

68. See text accompanying notes 19-22 supra.

69. See note 3 supra.

70. Brief of Superintendent of Insurance, reprinted in 101 BNA SEC. REg. L. REP. H-l, at $\mathrm{H}-3$ (May 12, 1971).
} 
hattan through the sale of assets which were classified as securities under the 1934 Act. If Begole had sold land belonging to Manhattan valued at five million dollars, again misappropriating the proceeds, all parties to this litigation would stand in the same position financially, but would have no 10b-5 claim. Further, if the Bankers Life test is applied to corporations whose assets include both eight month and ten month notes, identical in every respect except for time of payment, conversion of the former would not give rise to $10 \mathrm{~b}-5$ liability but conversion of the latter would. ${ }^{71}$ Such distinctions are analytically troublesome. Also, they will lead to what may be undesirable results. For example, since any sort of scheme remotely involving a security may become a $10 \mathrm{~b}-5$ violation, potential litigants will press for a loosening of the definition of "security," arguing that to do otherwise would only encourage

a certain class of gentleman of the "J. Rufus Wallingford" type-"they toil not, neither do they spin"- [to] lie awake nights endeavoring to conceive some devious and shadowy way of evading the law. ${ }^{22}$

Misappropriating Proceeds of an Innocent Sale of Securities. In his brief ${ }^{73}$ and in oral argument, ${ }^{74}$ the Superintendent asserted that mere conversion of proceeds from a sale of securities itself constitutes a violation of $10 \mathrm{~b}-5$. The Court indicated its interest in this theory by putting a hypothetical case to counsel for the plaintiff: "Suppose the sale had occurred. Then when the man was walking back from the bank, the idea of misappropriating the funds first came to him and he did this ...."75 The lawyer replied that the hypothetical stated a violation of $10 \mathrm{~b}-5$, but noted that the instant case was distin-

71. According to the 1934 Act, the definition of security "shall not include currency or any note, draft, bill of exchange, or banker's acceptance which has a maturity at the time of issuance of not exceeding nine months. . . " 15 U.S.C. $\$ 78(\mathrm{c})(\mathrm{a})(10)(1970)$.

72. State v. Whiteaker, 118 Ore. $656,661,247$ P. 1077,1079 (1926). In that case, arising under the Blue Sky Laws of Oregon, the defense was that the fraud did not involve a "security" as defined by those laws. The judge disagreed and for the reasons stated above, argued that the definition of "security" should receive a broad interpretation. It is submitted that one danger of basing 10b-5 culpability on the instrumentality-rather than the type of fraud-will be a blurring of the definition of "security" under the 1934 Act in an effort to foil modern-day "J. Rufus Wallingsfords." Compare Johnson v. Espey, __ F.2d _, (2d Cir. 1972) (10b-5 extended to cover commodity account) with McCurnin v. Kohimeyer \& Co., _ F. Supp. (E.D. La. 1972) (10b-5 does not cover commodity accounts).

73. Brief of Superintendent, note 70 supra, at $\mathrm{H}-4$.

74. See the excerpts from the oral arguments before the Supreme Court, reprinted in 40 U.S.L.W. 3173, at 3174 (U.S. Oct. 19, 1971).

75. Id. (the question was posed by Justice White). 
guishable since the alleged scheme preceded the sale. Apparently the Court found the distinction to have no legal significance, since it held the fact that the scheme involved a misappropration of proceeds was irrelevant, ${ }^{76}$ and cited several cases relied on by the Superintendent to support his argument that the conversion of proceeds-without proof of a scheme antedating the sale-violated the rule. ${ }^{77}$ Actually the cases cited involved the converse of the Superintendent's thesis-that is, the defendants had converted securities rather than proceeds. ${ }^{78}$ Since both types of cases involve conversions of property in connection with a sale of securities, these cases do lend superficial support to the Superintendent's proposition. However, unless this extension of $10 b-5$ liability is limited to fact situations such as the one presented by the Court's hypothetical where one of the parties to the securities transaction converts the proceeds within a short time of the transaction, the sweep of the rule can be boundless. Without such limitations 10b-5 would be violated by any conversion of corporate assets which could be even remotely traceable to a previous sale of securities.

Sale of Control to a Looter. Bankers Life moved to dismiss on the ground that it had no control over Manhattan at the time the bonds were sold. Although the Supreme Court expressed no opinion on the point, ${ }^{79}$ Bankers Life, while not participating in the sale of the bonds, could be liable on at least two theories. First, if it had conspired with Begole to sell Manhattan to him in order to allow him to loot the former Bankers Life subsidiary, then Bankers Life's acts would have been part of the scheme to defraud, readily cognizable under 10b-5. If Manhattan was not worth five million dollars, then the difference between its true value and the sale price of the shares could be regarded as a bribe..$^{89}$ The second and most intriguing theory of liability is suggested by Insuranshares Corp. v. Northern

76. 404 U.S. at 101.

77. Compare Brief of Superintendent, supra note 70, at $\mathrm{H}-4$ with Superintendent of Ins. of New York v. Bankers Life and Cas. Co., 404 U.S. 6, 10 n.7 (1971).

78. The Superintendent did cite one case which he claimed found culpability for a conversion of proceeds from an innocent sale. Parker v. Baltimore Paint \& Chem. Corp., 244 F. Supp. 267 (D. Colo. 1965). A close reading of the case reveals that the transaction was not analogous to Bankers Life; rather, Parker involved a buyer who refused to pay for securities which he had already received from the injured seller. Since the Supreme Court did not cite Parker, it apparently did not find the case helpful. See 404 U.S. at 10 n.7.

79. 404 U.S. at 13.

80. See text accompanying note 108 infra.

81. 35 F. Supp. 22 (E.D. Pa. 1940). 
Fiscal Corp., ${ }^{81}$ where holders of the controlling interest in an investment company sold it to a purchaser who financed the sale in much the same way that Begole did. ${ }^{82}$ The corporation sued its former controlling stockholders for breach of their state-law fiduciary duty to find a suitable buyer. In finding liability, the court stated that those who control a corporation owe a duty, in respect to the transfer of control to outsiders, not to transfer it if the circumstances surrounding the proposed transfer were such as to put a prudent man on his guard. Those selling a control block of stock must first satisfy themselves by means of a "reasonably adequate" investigation that no fraud was likely to result. ${ }^{83}$ One matter of importance to the Insuranshares court was "what was known or to be inferred as to the manner in which the purchase was to be financed." 84 A prudent seller, the court maintained, would want to know how three individuals could raise $\$ 310,000$ to buy control of a company. Similarly, if Bankers Life did not make a reasonable investigation into the background of Begole and the source of the five million dollars, its negligence would be a violation of the fiduciary duty owed to Manhattan. Moreover, the Supreme Court's opinion states a basis for finding Bankers Life liable under $10 \mathrm{~b}-5$ for such a breach:

The Congress made clear that "disregard of trust relationships by . . . fiduciaries, are all a single seamless web" along with manipulation, investor's ignorance and the like. . . Section 10(b) must be read flexibly, not technically and restrictively. ${ }^{85}$

The idea of so extending 10b-5 had heretofore been directly tested only once in court and abruptly dismissed. ${ }^{86}$ Since the corporation was neither a purchaser nor seller of its own stock, it lacked standing to sue under 10b-5 for harm arising out of sale of controlling interest

82. The buyers arranged for an unsecured loan for the purchase price with the understanding that, immediately after they achieved control, the company's portfolio of securities would be pledged to the lender as collateral. The lender would then sell as much of the portfolio as was needed to liquidate the debt and refund the balance to the buyers. In Bankers Life, Begole sold the securities himself, turning over the proceeds to the lender. In both cases, the company wound up paying for its own acquisition. $35 \mathrm{~F}$. Supp. at 25 .

83. Id.

84. Id. (emphasis added).

85. 404 U.S. at 11-12.

86. Erling v. Powell, 298 F. Supp. 1154 (D.S.D. 1969), aff d, 429 F.2d 795 (8th Cir. 1970). See Schwartz, The Sale of Control and the 1934 Act: New Directions for Federal Corporation Law, 13 Corp. Prac. Comm. 73, 76, 102 (1971) for the view that 10b-5 prohibits a sale of control whereby the corporation or the minority stockholders are treated unfairly. 
to looters. ${ }^{87}$ Although Manhattan likewise was not a purchaser or seller of its own shares, the Supreme Court's language may indicate that Bankers Life's motion for dismissal may not fare so well on remand. In the first place, the Superintendent can base his claim against Bankers Life on the fraud in connection with the bond sale on which he does have standing, arguing that it was a foreseeable result of the negligent sale of control. More significantly, he can make a strong argument that he now has standing to base his claim on the sale of control itself, for the Supreme Court's treatment of the whole issue of standing can be read as a final coup de grace for the purchaser-seller doctrine.

\section{Standing to Sue Under 10b-5 after Bankers Life}

Purchaser-Seller Requirement. The purchaser-seller requirement was not an issue on this appeal, since it dealt only with the sale of bonds in which Manhattan was unquestionably a seller. Consequently, the Court was not obligated to refer to the Birnbaum test at all. The Court's interest in examining the requirement, however, was apparent in the oral argument. Mr. Justice White asked the attorney for the SEC why he did not appeal the dismissal of the claim based on the sale of Manhattan's stock to Begole. The counsel candidly replied that he did not want the success of his case to hinge on the overturning of the Birnbaum ${ }^{88}$ rule. Denied the opportunity to examine the intricacies of the purchaser-seller doctrine, the Court pointedly noted that it expressed no opinion as to whether the Superintendent had standing on that claim. ${ }^{89}$ In making this point, the Court cited two commentators, one of whom argues that the requirement no longer exists, ${ }^{90}$ the other asserting that courts have failed to develop a consistent rationale in applying it." It is one thing for a court to have no opinion on an issue not before it; it is quite another matter to assert that the court does not have any such opinion. When this "non-opinion" is buttressed by citations to a commentator who is openly hostile to the rule and to another who finds the parameters of

87. See Loss $3614-19$, for the view that this type of case is distinguishable from Birnbaum, but that it might not be covered by $10 \mathrm{~b}-5$.

88. Oral Argument Before the Supreme Court, supra note 74.

89. 404 U.S. at 13 n.10.

90. Lowenfels, supra note 50.

91. Kellogg, The Inability to Obtain Analytical Precision Where Standing to Sue Under Rule l0b-5 is Involved, 20 BufFaLo L. REv. 93 (1970). 
the requirement to be uncertain, the assertion of a "non-opinion" becomes rather intriguing. Depending on which of the two commentators is more convincing to the Court, this "non-opinion" could mean either: (1) the parameters of the requirement are so uncertain that Manhattan might qualify as a purchaser of its own stock, an interpretation which would, on the facts of Bankers Life, radically alter the definition of "purchaser"; or (2) Manhattan was not a purchaser, but need not be. If this latter interpretation is correct the purchaser-seller doctrine is-finally-quite dead..$^{92}$

An Enlarged Class of 10b-5 Plaintiffs? Creditors' Derivative Actions. If read technically and restrictively, Bankers Life is not a creditors" "derivative" action. An order commencing liquidation proceedings of an insurance company vests the Superintendent as liquidator with all causes of action formerly belonging to the insurer. ${ }^{03}$ Instead of creditors bringing suit on behalf of Manhattan for the ultimate benefit of creditors, this suit was brought by the legal representative of Manhattan on behalf of Manhattan-for the benefit of creditors. This distinction, probably incomprehensible to a layman, clearly exalts form over substance, but it has been a necessary one. As counsel for the Superintendent conceded, creditors do not ordinarily have the right to bring suit on behalf of the corporation, although

92. Although the Court's apparent view of the purchaser-seller requirement may alarm those for whom it has been one of the eternal verities of securities law, it is arguable that the famous rule must fall when measured against contemporary tests for determining standing. Repetition of the Birnbaum holding obscures the fact that the Birnbaum rule itself must be tested by ordinary standing requirements. While "[g]eneralizations about standing to sue are generally worthless as such," Association of Data Processing Serv. Organizations v. Camp, 397 U.S. I50, I5I (1970), the Court has stated that article III of the Constitution requires that the plaintiff allege that he has suffered a genuine injury. Id. at 152 . When the law under which he seeks relief has limited applicability, the plaintiff must show that he is protected by it. See, e.g., ReSTATEMENT (SECOND) OF TORTS $\S 286$, eomment $f$. Birnbaum expressly held that a non-purchaser or seller was simply not protected by $10 \mathrm{~b}-5$. See note 55 supra. But the granting of injunctive relief to those who did not meet the Birnbaum test should have undercut that argument. See note 54 supra. Nevertheless the standard has continued to be applied to damage claimants, perhaps on the unarticulated assumption that, without a specific purchase or sale, they could not demonstrate the existence of an injury which could be redressed by a court. Id. Even this rationale loses some of its force when one considers the cases awarding damages for incomplete transactions in which the plaintiff's loss would necessarily have to be estimated. See notes 59-60 supra. In conclusion, it would seem that a plaintiff who can meet the tests for standing articulated by the Supreme Court should not be forced to surmount another obstacle erected by one of the circuits.

93. See note 7 supra. 
shareholders do. ${ }^{94}$ This disparity of treatment may seem justifiable in view of the difference between the creditor-debtor and shareholdercorporation relationships. The stockholder by definition owns a part of the corporation, a portion whose value increases and decreases in relation to the earnings of the company. In contrast the creditor's interest is fixed; no matter how skillfully the corporation is managed, he may demand no more than the amount owed him. If the debtor corporation defaults, then the creditor's action is on the debt itself; whether the failure to pay was caused by fraud, larcency, or merely a down-turn in the business cycle ordinarily is of no concern to the creditor. ${ }^{95}$

Persuasive arguments in favor of a creditors' derivative action may be made, however, particularly on the facts of Bankers Life. Shareholders can bring actions on behalf of a corporation since they stand in such a relationship to it that an injury to the corporation is an injury to them. They do bring such actions because the directors refuse to sue, often because the directors would be defendants in the suit. ${ }^{96}$ However, it is clear that corporate mismangement, particularly when it is as egregious as Begole's, can greatly jeopardize the security of the creditor's position. Where the sole stockholder is himself the swindler, as in Bankers Life, it is equally apparent that no one except the creditor will sue to recover the damages suffered by the corporation. ${ }^{97}$ Moreover, the Bankers Life opinion emphasized the fact that directors and controlling shareholders owe a fiduciary duty to the corporation for the sake of creditors as well as shareholders. ${ }^{98}$ As beneficiaries of that duty, creditors should be allowed to enforce it by bringing derivative actions, particularly when others will not seek judicial relief.

Direct Creditor Standing. The Supreme Court's concern for the

94. See oral argument, note 74 supra. Rule 23.1 of the Federal Rules of Civil Procedure expressly provides for shareholder derivative actions. There is no corresponding "Creditors Derivative" action.

95. Not only may creditors not sue to enjoin mismanagement of the debtor corporation, but they may not enjoin merger of the debtor with another corporation merely because the consolidated company's quick asset condition made it a less desirable debtor. See Cole v. National Cash Credit Ass'n, 18 Del. Ch. 47, 156 A. 183 (1931).

96. A stockholder's derivative action alleges two wrongs, an act which caused damage to the corporation and a refusal of the corporation itself to redress that act. Druckerman v. Harbord, 174 Misc. 1077, 22 N.Y.S.2d 595 (Sup. Ct. 1940).

97. Unless, of course, the corporation is thrown into receivership or bankruptcy as happened here.

98. 404 U.S. at 12. 
creditors of a defrauded corporation leads to the question of whether creditors may now claim that they,.as creditors, have been deceived by a fraudulent transaction involving the purchase or sale of corporate securities. A creditor's derivative action might logically be brought by those parties who were creditors at the time of the fraud, since their claim is predicated on damage to the corporation which affects their interests. A creditor who loans money to a company after the fraudulent transaction stands in a different position. His complaint is based on detrimental reliance on the false picture of financial health presented by the corporation's books. To the extent that the books misrepresent the effects of a fraudulent securities transaction, a creditor may claim he was deceived in connection with that transaction. ${ }^{99}$ Again, the main barrier to the individual creditor action is, of course, the hoary purchaser-seller requirement. Since the damages alleged by a creditor would not be the result of a securities transaction in which he was either purchaser or seller, he would lack standing to bring the action. If parts of the Bankers Life opinion may be read at least as a broad hint that the Supreme Court has decreed the demise of the purchase-seller requirement, ${ }^{100}$ this main bar to the creditors' action may be removed. Moreover, the Supreme Court's concern for creditors would seem hollow indeed if they are forced to wait until the debtor company is bankrupt-by definition unable to pay its debts-before bringing a $10 \mathrm{~b}-5$ action to protect themselves from the consequences of a transaction which jeopardizes their chance of ever being paid.

\section{Judicial Response to Bankers Life}

The initial reaction of the lower courts to Bankers Life was cautious. As a result of this decision, the Second Circuit sitting en banc reversed an earlier panel decision in Drachman v. Harvey, ${ }^{101}$ but did so on the narrowest grounds possible. Drachman was a derivative action brought against the officers and former majority shareholders of a corporation, alleging fraud in connection with the defendants' sale of control of the corporation at a premium and their subsequent redemption of all of the company's convertible debentures. While

\footnotetext{
99. See, e.g., Bailes v. Colonial Press, Inc., 444 F.2d 1241 (5th Cir. 1971). See note 65 supra.

100. See notes 88-92 supra and accompanying text; see text accompanying notes $110-11$ infra.

101. 453 F.2d 722 (2d Cir. 1971).
} 
having an adverse effect on the corporation financially, ${ }^{102}$ the redemption of the convertible debentures consolidated the controlling interest of the control-purchaser. ${ }^{103}$ The Second Circuit's panel court felt bound by their decision in Bankers Life, which the court considered to be analogous to Drachman. ${ }^{104}$ Since the corporation neither bought nor sold the controlling interest, there was no derivative standing for the shareholders as to that transaction. Further, the court found it unnecessary to decide that a redemption of outstanding bonds was a purchase since the bonds were redeemed for a fair price. ${ }^{105}$ For rule $10 \mathrm{~b}-5$ to be violated, the court asserted, the plaintiff must claim that "the alleged fraud between the parties and/or alleged market manipulations or deception is intrinsic to the securities transaction itself." 106 After the Supreme Court decision in Bankers Life, Drachman was reheard by the Second Circuit sitting en banc, which read Bankers Life to hold that $10 \mathrm{~b}-5$ was violated whenever a purchaser or seller suffers injury as a result of deceptive practices in connection with a sale of securities. ${ }^{107}$ Redemption of convertible debentures was held to be a purchase of securities, thus giving the corporation standing as to that claim. Further, the court ruled that the allegation of the sale of control stock at a premium stated a breach of state law fiduciary duty, which a federal district court could hear only under the doctrine of pendent jurisdiction. ${ }^{108}$ Having thus avoided the problems raised by Bankers Life, the en banc court triumphantly announced that there was no need to review the present limits of Birnbaum at that time.

A bolder approach was taken by a New Jersey district court in Tully v. Mott Supermarkets, Inc. ${ }^{109}$ In that case the plaintiffs had owned a controlling interest in a close corporation. To secure this

102. All of the debentures were convertible into common stock. When they were redeemed, the purchaser's interest was protected against dilution by conversion of the debentures. Id. at 725.

103. In order to obtain operating capital the company was forced to borrow in a period of high interest rates. Id. at 725 .

104. Id. at 730-33. Drachman is actually more similar to Birnbaum itself. See text accompanying notes $42-43$ supra.

105. 453 F.2d at 732.

106. $I d$.

107. Id. at 737.

108. Id. at 738. Since the case involved the same parties litigating federal and nonfederal claims arising out of the same transactions, the en banc court found that pendent jurisdiction was proper. See generally C. WRIGHT, FEDERAL CourTs 62-65 (2d ed. 1970).

109. 337 F. Supp. 834 (D.N.J. 1972). 
control they had an agreement with other shareholders which gave the plaintiffs a right of first refusal on any shares sold by them or issued by the company. The directors, defendants in the action, secretly sold treasury stock to certain third parties breaching the agreement and giving these third parties, also defendants, control of the corporation. When the defense pointed out that the plaintiffs qualified neither as purchasers nor sellers of the shares in question, the court responded that such an argument sought to "revive the spectre of the Birnbaum buyer-seller doctrine at a point in time when both courts and legal scholars are seeking to bury it." 110 Significantly, the court in Tully found that the continued existence of the purchaserseller doctrine was incompatible with the Bankers Life command that section $10(b)$ be read flexibly rather than technically and restrictively. In rejecting the Birnbaum standard, the district court stated that the new test of standing was one of causation:

where there is a causal connection between the purchase or sale of stock, the alleged fraud or breach of fiduciary duty, ar,d plaintiffs loss then federal jurisdiction under 10b-5 exists."'

Finally, lest any future court or commentator seek to distinguish Tully on the ground that the relief sought was an injunction, the court declared that the choice of remedy had no bearing whatsoever on the plaintiff's standing to bring the action. ${ }^{12}$

\section{Conclusion}

Until more lower courts apply Bankers Life to specific fact situations, it will be far easier to curse the obscurity of the opinion than to illuminate it. A court could be justified in saying that Bankers Life left the state of $10 \mathrm{~b}-5$ law virtually unchanged, or that it made $10 \mathrm{~b}-5$ a universal solvent for all types of breaches of fiduciary duty and a great triumph for the new "federal corporation law." If the case is limited strictly to its facts and precise holding, it amounts to nothing more than an assertion that a trustee in bankruptcy, vested by law with all of the rights of a corporation, can bring an action under 10b5 when those in a fiduciary relationship with the bankrupt company

110. Id. at 839 (emphasis added).

111. Id. at 842 .

112. "Defendants have apparently confused subject matter jurisdiction with the notion of remedy." Id. at 840 . The defendants had claimed that the buyer-seller requirement could be used when a prospective injunction was sought. The Tully court granted a retrospective injunction and therefore brushed aside the defendant's attempted distinction. 
have duped it into selling securities so that the proceeds could be put to the private use of the fiduciaries.

On the other hand, the opinion invites a much broader application. It could be concluded, without doing violence to the opinion, that the Court would allow creditors of a corporation to bring $10 \mathrm{~b}-5$ actions for breaches of fiduciary duties owed to them; that the Court finds the Birnbaum purchaser-seller doctrine to be ill-defined and indefensible; and that negligent sale of a controlling interest to a looter states a violation of $10 \mathrm{~b}-5$. At present, however, $10 \mathrm{~b}-5$ resembles a person who has recently undergone plastic surgery. The surgeon has made no specific promises regarding the results, and most of the bandages have yet to be removed. Until they are, all who deal with 10b-5-plaintiffs, commentators, and, most of all, defense lawyers-can only guess and hope that they are right. 
$\because$ 